\title{
RESPONSIBILITIES OF BUSINESS ACTORS ON FOOD SANITATION REVIEWED FROM CONSUMER PROTECTION LAW
}

\author{
Khifni Kafa Rufaida \\ Ngudi Waluyo University \\ Khifnikafarufaida@gmail.com
}

\begin{abstract}
The purpose of this research is to overcome the awareness problem of business actor, especially street vendors and consumer on the importance of hygiene and food sanitation, to identify how big the responsibility of business actors (Street Vendors) to products sold under the UUPK. This research is also a form of Research Grant for Beginner Lecturers, which was expected to direct and nurture the ability to research novice lecturers, and become a training tool for novice lecturers to publish their research results in accredited scientific journals, both locally and nationally. The results showed that the level of awareness of business actors on food sold is still lacking, it is also supported by the lack of consumer awareness of the importance of protection of consumers. The form of responsibility of business actors (street vendors) is to provide compensation to the disadvantaged consumers under Article of the Protection Act of Consumers.
\end{abstract}

\section{Keywords; Street Vendors; Food Sanitation; Consumer Protection.}

\section{A. INTRODUCTION}

Science and technology that developed today is known by the abbreviation IPTEK. In Big Indonesian Dictionary which is meant by knowledge is knowledge or skill about worldly matter, hereafter, birth, mind, and so on. ${ }^{1}$ Health problems are complex problems that are related to other issues beyond the health problem itself. Public health problem solving is not only in terms of health, but it also must be viewed from all aspects of the effect on the problem of "healthy sickness" or health. According to the Ministry of Health of the Republic of Indonesia many factors affected the degree of health, both individual health and public health. One of them is hygiene and food sanitation.

As a developing country, hygiene and food sanitation problems are a long-standing and recurring problem in our country of Indonesia. Street vendors as business actors are often labeled as traders who have low responsibility for the quality of products offered to consumers. Food sold on the side of the road we usually call as street vendors such as, siomay, batagor, seblak, cilok, and others Based on the Decree of Minister of Health of the

\footnotetext{
${ }^{1}$ Anis Mashdurohatun, Redyanto Sidji, Gunarto and Mahmutarom, Factors Causing Banking Cyber Crime in Indonesian, International Journal of Economic Research, Volume 14 Number 15 2017. P.295
} 
Republic of Indonesia No. 1096/Menkes/PER/VI/2011 food processing must meet the elements sanitary hygiene as set forth in the Annex to the Minister of Health Decree. This lack of awareness of sanitation hygiene should be addressed immediately so that consumer protection is realized.

Health problems caused by unhygienic foods are certainly is very detrimental to consumers. The term consumer connotes varies. With the enactment of Law No. 8 of 1999 on Consumer Protection (UUPK), the word consumer means people who use goods/services available in the community for their own/family/other/other living things, and not for trading. So, the consumer here is the end consumer. Medium street vendors associated with the community, clearly not clearly in the position of business actors dealing with consumers.

For example, the absence of a license granted to a street vendor has weakened the government's government-controlled spectrum of the products they sell. The absence of this oversight is clearly very detrimental to consumers. The report of the Food and Drug Supervisory Agency (BPOM) on food/beverage products traded by street vendors, recently showed quite a lot of food samples (including meatballs, tofu, wet noodles, syrup and cendol) that have been contaminated with hazardous materials such as formaldehyde, borax, rhodamine $\mathrm{B}$, benzoate, saccharin, and cyclamate. Food/beverages include salmonella because it is produced unhygienic.

The addition of these hazardous materials of course has a certain purpose, which again is very pragmatic. The use of rhodamine B dyes, for example, is done to provide a special attraction for consumers. Light-colored cendol ice is seen more inviting consumer tastes than dark-colored cendol ice but natural.

Based on the above description, the author's aim to conduct this research was to examine more deeply the awareness of the importance of hygiene and food sanitation in relation to consumer protection laws. Here are some research questions 1 ) how is the level of awareness of business actors and consumers of the importance of food sanitation? and 2) what is the responsibility form of business actor for loss suffered by consumer based on Consumer Protection Law.

\section{B. DISCUSSION}

\section{Food Sanitation}


Sanitation is a disease prevention effort that focuses on the activities of the health of the human environment. Efforts to maintain the maintenance of a person, food, workplace or equipment remain hygienic (healthy) and pollution-free resulting from bacteria, insects, or other animals. Sanitation is a preventive health business that focuses its activities on the health of the human environment

Food Sanitation is a disease prevention that focuses its activities on environmental health where food and beverage is located (Food and Beverage environment). So Food Sanitation emphasizes on environmental factors such as processing equipment, processing places, food presentation, and others.

Food sanitation is one of the prevention efforts that emphasizes the activities and actions necessary to free food from all dangers that can interfere with or damage health, from before the food is produced, during processing, storage, transportation, to the time when the food is ready to be consumed to the public or consumers. Food sanitation aims to ensure the safety and purity of food, prevent consumers from disease, prevent the sale of food that will harm the buyer, reduce food damage.

The principle of hygiene and food sanitation is the practical and sanitation of food. According to the Ministry of Health of the Republic of Indonesia the principles of food hygiene sanitation include:

1. Selection of foodstuffs;

2. Storage of foodstuffs;

3. Food processing;

4. Food storage;

5. Transportation of food, and;

6. Presentation of food.

According to Health Department of the Republic of Indonesia (Depkes RI) Food consumed should meet the criteria that the food is feasible to eat and not cause disease, including:

a. Be in the desired degree of cooked.

b. Free from pollution at each stage of production and subsequent handling.

c. Free from undesired physical, chemical changes, as a result of enzymatic influences, microbial activity, rodents, insects, parasites and pressure, cooking and drying damage.

d. Free from microorganisms and parasites that cause food-borne diseases. 


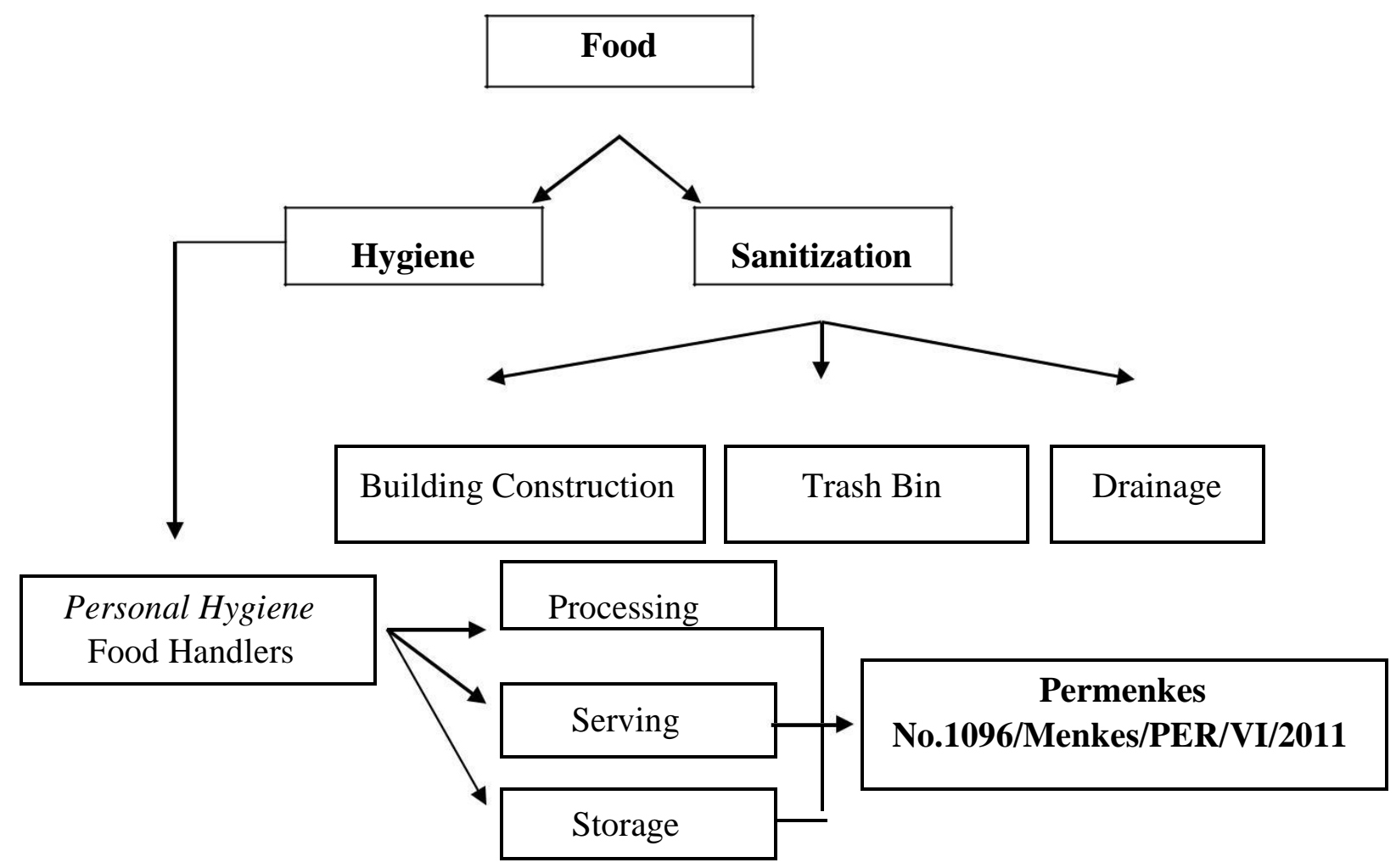

2. Rights and Obligations of Business and Consumer Actors Based on Law no. 8 of 1999 on Consumer Protection

Consumer protection is any effort that ensures legal certainty to provide protection to consumers. Consumer protection is based on benefits, fairness, equilibrium, consumer safety and security, and legal certainty (Article 2). Consumer protection aims (Article 3):

a. To increase awareness, ability and independence of consumers to protect themselves;

b. To raise the consumer's dignity and prestige by avoiding it from negative excesses of goods and / or services;

c. To improve consumer empowerment in choosing, determining and demanding their rights as consumers;

d. To create a consumer protection system containing elements of legal certainty and information disclosure and access to information;

e. To foster business acknowledgment about the importance of consumer protection so as to grow an honest and responsible attitude in the business; 
f. To improve the quality of goods and / or services that ensure the viability of goods and/or services production, health, convenience, security, and consumer safety.

Consumer rights are (Article 4):

a. The right to comfort, safety in consuming goods and/or services;

b. The right to choose goods and/or services and obtain the goods and/or services in accordance with the exchange rate and the conditions and promised warranties;

c. Right to true, clear and honest information about the condition and guarantee of goods and/or services;

d. The right to be heard of his opinions and complaints on the goods and/or services used;

e. The right to appropriate advocacy, protection and dispute resolution efforts;

f. The right to counseling and education of consumers;

g. The right to be treated or served properly and honestly and not discriminatively;

h. The right to compensation, indemnification and/or reimbursement, if the goods and/or services received are not in accordance with the agreement or not as they should be;

i. Rights set forth in the provisions of other laws and regulations.

Consumer liabilities are (Article 5):

a. To read or follow instructions on information and procedures for the use or use of goods and/or services, for security and safety;

b. To have good faith in the purchase of goods and/or services;

c. To pay according to the agreed exchange rate;

d. To follow the appropriate dispute settlement of consumer protection dispute law.

The rights of business actor are (Article 6):

a. The right to receive payment in accordance with the agreement on the conditions and exchange value of goods and/or services traded;

b. The right to legal protection from misconducted consumer acts;

c. The right to self-defense should be appropriate in the settlement of consumer disputes law; 
d. The right to the rehabilitation of a good name if it is legally proven that the consumer's loss is not attributable to the goods and/or services being traded;

e. rights set forth in the provisions of other laws and regulations.

The obligations of business actors are (Article 7):

a. To have good faith in doing business;

b. To provide true, clear and honest information about the condition and guarantee of goods and / or services and provide explanations of use, repair and maintenance;

C. To treat or serve consumers properly and honestly and non-discriminatively;

d. To guarantee the quality of goods and/or services produced and/or traded under the provisions of the applicable quality standards of goods and/or services;

e. To provide an opportunity for consumers to test, and/or try certain goods and/or services and provide guarantees and/or warranties on manufactured and/or traded goods;

f. To compensate, indemnify and/or reimburse for losses arising from the use, use and utilization of traded goods and/or services;

g. To compensate, indemnify and/or reimburse if the goods and/or services received or utilized are not in accordance with the agreement.

\section{Level of awareness of business actors and consumers on the importance of food sanitation}

Based on the results of research conducted by the author in the Field of FoodHygiene at the District Health Office of Semarang that to assess whether the food meets sanitary hygiene elements can be assessed from the following components, among others:

a. Food Ingredients

1) Foodstuffs in fresh condition, not foul and undamaged;

2) Does not contain toxic hazardous materials (pesticides and heavy metals);

3) Does not contain hazardous materials such as formalin, borax, and others.

b. Ready Food

1) Does not contain toxic hazardous materials (pesticides and heavy metals); 
2) Does not contain hazardous materials such as formalin, borax, and others;

3) Food additives meet the requirements of applicable laws and regulations;

4) For easily damaged food, the number of $E$ coli 0 germs;

5) Not slimy, not moldy;

6) Not expired.

c. Food Storage

1)Separate food storage with ready food;

2)In the storage area there should be no pesticide material (B3);

3)Free from annoying insects such as flies.

d. Food Processing Equipment

1)Food processing equipment shall be clean, not cracked, not faded, not corroded;

2)Using napkins/wipes clean and not dirty;

3) There is enough water to wash food utensils.

e. Presentation/Sales of Food

1)The serving container should be closed, not open;

2)Etalase easy to clean, not rusty, not made of toxic hazardous materials (lead, arsenic, copper, cadmium and others).

f. Sanitation Facility

1) Availability of clean water in sufficient quantity;

2)Environment free from insects;

3)Environment free from air pollution.

From the above components, after the research on Consumers and street vendors as Business Actors:

a. Street Vendors as Manufacturers

From the results of research that has been conducted by the author on street vendors (PKL), in the food presentation of street vendors stated that the food equipment is stored in a clean place and avoid insects (such as flies) and environmental pollution. However, when viewed the surrounding neighborhood where street vendors are not free from air pollution and dust that fly in the area of food sales. Surely this condition not only contaminates the existing food equipment, but also contaminates the food to be consumed by consumers. 
For the food presentation, in general, street vendors serve it by wrapping food with white plastic. However, there are some street vendors who provide bowls or dishes to serve food. According to the recognition from the street vendors that bowls and dishes are always washed after being used by consumers. However, the authors observed that water used for washing is not water that flows but water is placed in a bowl and used to wash different bowl/plate and only occasionally replaced or even not replaced at all.

\section{b. Student as Consumer}

From the results of research that has been done by the author on the consumer, the street vendors are very attractive consumers because the price is cheap and affordable. According to the author's opinion, snacks suitable for students' pockets are street vendors (PKL) because the price is very friendly and certainly easy to obtain. But the thing to note is why the majority of consumers prefer the price is more affordable than the quality of food consumed? Even some consumers who claimed to have abdominal pain after consuming street vendors but not deterrent to continue to consume food vendors.

According to Article 1 Sub-Article 3 of the Consumer Protection Law (UUPK), a business actor shall be an individual or business entity, whether incorporated as a legal entity or not a legal entity, established and domiciled or conducting activities within the territory of the Republic of Indonesia, together through agreements to conduct business activities in various economic fields. From that definition, street vendor (PKL) is also one of the business actors conducting business activities within the jurisdiction of Indonesia.

Awareness of the importance of food sanitation is very important, this awareness will give birth to a step or effort to realize consumer protection. Of course, if consumers are protected from contaminated foods, it will affect the progress of business actors. The concrete form of consumer awareness is the ability of consumers to protect themselves from foods that will harm their own health. A consumer who is aware of the importance of food sanitation will try to avoid the negative access to consume food.

Meanwhile, the concrete form of business actor consciousness is that he will continue to strive to deceive consumers by creating consumer protection that contains elements of legal certainty and information disclosure about the food he made. If this awareness has been fed, there arises honesty and responsibility in running the business and continue to increase food produced for the safety and comfort of consumers. 
From the results of the research above, it shows that the level of awareness of street vendors and Students as producers and consumers is still very less. The results of interviews with Consumer who had suffered immaterial losses, so far consumers who have experienced losses tend to be passive and silent. This passive attitude indicates that there is no awareness of the importance of consumer self-protection from dishonest business actors. Consumer unconscious will spur business actors to continue doing dishonest business which certainly does not reflect the efforts to protect consumers.

\section{The form of business actor responsibility for the loss suffered by consumers based on the Consumer Protection Law}

As a Business Actor, a street vendor is required to be responsible for hygiene and sanitation on food he sold. Good hygiene sanitation food and beverages need to be supported by environmental conditions and good sanitation facilities as well. The facilities include:

(1) The availability of adequate clean water, in terms of quantity and quality;

(2) A properly disposed waste water disposal so as not to become a source of pollution;

(3) A garbage dump made of waterproof material, easy to clean, and has a lid. Poor sanitary hygiene conditions can affect the quality of food served to consumers.

This obviously will also affect the level of health of consumers who consume these foods. ${ }^{2}$ According to Article 5 paragraph (1) "Management of food by jasaboga must meet sanitation hygiene and carried out according to good food processing." In the attachment of Decree of Minister of Health RI No 1096/Menkes/PER/VI/2011 on Hygiene Sanitation Jasaboga that Food consumed must be hygienic, healthy and safe that is free from physical, chemical and bacterial contamination. Physical contaminants such as broken glass, gravel, pieces of stick, hair, staples, and so on. Chemical contaminants are such as Lead, Arsenicum, Cadmium, Zinc, Copper, Pesticides and so on. Bacterial contaminants are such as Escherichia coli (E.coli) and so on.

The responsibility of this business actor has been clearly regulated in the form of an obligation of business actor in Article 7 UUPK, as follows:

a. Have good faith in doing business;

\footnotetext{
${ }^{2}$ Yulia, Higiene Sanitasi Makanan, Minuman dan Sarana Sanitasi Terhadap Angka Kuman Peralatan Makan Dan Minum Pada Kantin, Jurnal Vokasi Kesehatan, Volume II Nomor 1 January 2016, Page. 56
} 
b. Provide true, clear and honest information about the condition and guarantee of goods and/or services and provide explanations of use, repair and maintenance;

c. Treat or serve consumers properly and honestly and non-discriminatively;

d. Guarantee the quality of goods and/or services produced and/or traded under the provisions of the applicable quality standards of goods and/or services;

e. Provide an opportunity for consumers to test, and/or try certain goods and/or services and provide guarantees and/or warranties on manufactured and/or traded goods;

f. Compensate, indemnify and/or reimburse for losses arising from the use, use and utilization of traded goods and/or services;

g. Compensate, indemnify and/or reimburse if the goods and/or services received or utilized are not in accordance with the agreement.

In addition to being regulated, the obligations of business actors in the Consumer Protection Law are also regulated on the acts prohibited by the business actors, among others are:

a. Not meet or fail to comply with the required standards and rules of legislation;

b. Not in accordance with net weight, net or net contents, and quantities in the counts as stated in the label or label of the goods;

c. Not in accordance with the size, dosage, scales and quantities in the count according to actual size;

d. Not in accordance with conditions, warranties, privileges or efficacies as stated in the label, label or description of such goods and/or services

e. Not in accordance with the quality, grade, composition, processing, style, mode, or specific use a stated in the label or description of the goods and/or services;

f. Not in accordance with the promise stated in the label, etiquette, description, advertisement or promotion of the sale of the goods and/or services;

g. Not include the expiration date or the best usage period/utilization of certain goods;

h. Not follow the terms of producing halal, as "halal" statements contained in the label;

i. Not put a label or make an explanations of goods containing the name of the goods, size, weight / net or net contents, compositions , rule of use, date of 
manufacture, side effects, name and address of business actor and other information for use according to which conditions shall be installed;

j. Not include information and / or instructions on the use of goods in the Indonesian language in accordance with applicable laws and regulations.

In Article 8 paragraph (2) it is stipulated that: "Business actors are prohibited from trading of damaged, defective or used goods and polluted without providing complete and correct information on the goods." From the provision can be concluded that the street vendors around UNW clearly perform prohibited acts, because food sold by street vendors polluted with air pollution and still found insects that roam around the street vendors selling.

Further, business actors who violate paragraph (1) and paragraph (2) are prohibited to trade such goods and/or services and must withdraw them from circulation. A food can be said hygienic if it has been in accordance with the existing standards in terms of equipment, processing, place of processing, presentation of food and environmental factors where he sell/trade goods. A good standard of a food is when the above components are met.

The need for street vendors' awareness of food sanitation is a measure to prevent illnesses that focus on the activities and actions necessary to free food and beverages from all hazards that may interfere with health, from before the food is produced, during processing, storage, transport to the point where food and beverages are ready to be consumed to the public or consumers.

From the above description, the authors conclude that the responsibilities of street vendors of food (products) are sold still very less, proven:

1. Street Traders generally do not cover finished food to be sold so that the food is contaminated/polluted with air pollution;

2. Street Traders generally ignore the flying insects around the food being traded;

3. Unavailability of sufficient clean and flowing water so that sanitation of food is to be sold to the consumers.

Losses in law can be qualified into two forms: material losses and immaterial losses. A material loss is a real loss and suffered by someone. While the loss of immaterial is the loss of benefits that may be received by someone in the future or loss of loss of profit that someone actually received in the future. The disadvantages to be discussed in this research are the losses suffered by the street seller's consumers to food sold by street vendors either in material or immaterial form. The consumer losses of street vendors 
occur due to lack of awareness of the important of consumer protection. One form of loss is a material loss that consumers can not enjoy food purchased because there are differences in the taste of the food they buy. Medium form of immaterial losses is a stomach ache suffered by the consumer.

If a consumer is harmed after consuming the food traded by a street vendor, then the street vendor as the business actor must be responsible to compensate the losses suffered by the consumers. Subject to the provisions of Article 19 paragraph (1) UUPK of business actors is responsible to provide compensation for damage, pollution and or loss of consumers due to consuming traded food.

Furthermore, in paragraph (2) the same Article shall be mentioned the form of indemnification in question, among others:

a. refund or;

b. replacement of similar or equivalent value or;

c. health care;

d. giving compensation in accordance with the provisions of legislation.

Then, when should the street vendors provide compensation to consumers who suffered the loss? According to Article 19 paragraph (3): "granting compensation within a period of 7 (seven) days after the date of the transaction."

\section{CONCLUSION}

The level of awareness of business actors and consumers on the importance of food sanitation is still lacking because consumers who suffer losses due to food traded street vendors tend to be passive and silent. This has resulted in the lack of responsibility of business actors (street vendors) of products sold to the public. Street vendors that cause consumers to suffer losses then based on the Business Actors must replace the losses suffered by consumers. The forms of liability may include refunds, the compensation of goods of equal value, health care or compensation in accordance with applicable laws and regulations.

\section{BIBLIOGRAPHY}

Anis Mashdurohatun, Redyanto Sidji, Gunarto and Mahmutarom, Factors Causing Banking Cyber Crime in Indonesian, International Journal of Economic Research, Volume 14 Number 152017

Depkes RI. 1994. Pedoman Pengelolaan dan Penyehatan Makanan Warung Sekolah. Jakarta. 
Dewi, YS. 2008. Higiene dan Sanitasi Pengelolaan Makanan pada Sentra Pedagang Makanan Jajanan Kesawan Square dan Pagaruyung Medan Tahun 2008. Skripsi FKM USU. Medan.

Prabu. 2008. Higiene dan Sanitasi Makanan. http//gmpg.org. Jakarta. Diakses Tanggal 13 Juni 2009.

Yulia, Higiene Sanitasi Makanan, Minuman dan Sarana Sanitasi Terhadap Angka Kuman Peralatan Makan Dan Minum Pada Kantin, Jurnal Vokasi Kesehatan, Volume II Nomor 1 Januari 2016.

Kitab Undang-Undang Hukum Perdata.

Undang-Undang Nomor 8 Tahun 1999 tentang Perlindungan Konsumen. 